\title{
Ecomorphological differences between Rhamdia (Bleeker, 1858) populations from the Iguaçu River basin
}

\author{
Fabio Teruo Mise ${ }^{1,3}$, Luiz Fernando Caserta Tencatt ${ }^{1}$ \& Fagner de Souza ${ }^{2}$ \\ ${ }^{1}$ Programa de Pós-graduação em Ecologia de Ambientes Aquáticos Continentais, Universidade Estadual \\ de Maringá - UEM, Av. Colombo, 5790, CEP 87020-900, Maringá, PR, Brasil \\ ${ }^{2}$ Coleção Ictiológica do Núcleo de Pesquisa em Limnologia, Ictiologia e Aquicultura - NUPÉLIA, \\ Programa de Pós-graduação em Biologia Comparada, Universidade Estadual de Maringá - UEM, Av. \\ Colombo, 5790, CEP 87020-900, Maringá, PR, Brasil \\ ${ }^{3}$ Corresponding author: Fabio Teruo Mise, e-mail: fabio_mise@hotmail.com
}

MISE, F.T., TENCATT, L.F.C. \& SOUZA, F. Ecomorphological differences between Rhamdia populations (Bleeker, 1858) from the Iguaçu River basin. Biota Neotrop. 13(4): http://www.biotaneotropica.org.br/v13n4/ en/abstract?article+bn01513042013

\begin{abstract}
Morphological and genetic evidences suggest that Rhamdia branneri and Rhamdia voulezi, currently considered synonymous of Rhamdia quelen, are in fact two valid species. Furthermore, in the taxonomic revision of $R$. quelen, no exemplars from the Iguaçu River were examined, which makes the synonymy doubtful. Considering the two species as valid, it was hypothesized that $R$. branneri and $R$. voulezi have ecomorphological differences, with the objective to verify if they can be considered ecologically distinct. Ecomorphological characterization was conducted using ecomorphological indices. For statistical analysis, a Principal Component Analysis (PCA), a Multiresponse Permutation Procedure (MRPP), and a Discriminant Analysis (DA) were performed. The ordination provided by the PCA evidenced ecomorphological separation, with $R$. branneri having morphological aspects related to benthic fishes, and $R$. voulezi having morphological characteristics related to pelagic and lentic habitats. The DA results confirmed the morphological tendencies found in the PCA, and the MRPP showed significant statistical differences between the ecomorphology of Rhamdia species. In this way, the initial hypothesis can be corroborated. These results allied to information about diet, genetics, and reproduction can be helpful for the elucidation of the taxonomic status of $R$. branneri and $R$. voulezi.
\end{abstract}

Keywords: endemism, Heptapteridae, Rhamdia voulezi, Rhamdia branneri, Rhamdia quelen, ecomorphology.

MISE, F.T., TENCATT, L.F.C. \& SOUZA, F. Diferenças ecomorfológicas entre populações de Rhamdia (Bleeker, 1858) da bacia do rio Iguaçu. Biota Neotrop. 13(4): http://www.biotaneotropica.org.br/v13n4/pt/ abstract?article+bn01513042013

Resumo: Evidências morfológicas e genéticas sugerem que Rhamdia branneri e Rhamdia voulezi, atualmente consideradas sinônimas de Rhamdia quelen, são, de fato, duas espécies válidas. Adicionalmente, na revisão taxonômica de $R$. quelen nenhum exemplar do rio Iguaçu foi examinado, o que torna a sinonímia duvidosa. Considerando as duas espécies como válidas, foi testada a hipótese de que $R$. branneri e $R$. voulezi possuem diferenças ecomorfológicas, com o objetivo de verificar se elas podem ser consideradas ecologicamente distintas. A caracterização ecomorfológica foi conduzida utilizando os índices ecomorfológicos. Para a análise estatística foram feitas Análise de Componentes Principais (ACP), Procedimento de Permutação Multiresposta (PPMR) e Análise Discriminante (AD). A ordenação proveniente da ACP evidenciou separação ecomorfológica, com $R$. branneri possuindo aspectos morfológicos relacionados a peixes bentônicos e $R$. voulezi possuindo características morfológicas relacionadas a habitats pelágicos e lênticos. Os resultados da AD confirmaram as tendências morfológicas encontradas na ACP, e o PPMR mostrou diferenças estatísticas significativas entre as espécies de Rhamdia. Dessa maneira, a hipótese inicial pôde ser corroborada. Esses resultados, aliados a informações sobre a dieta, genética e reprodução, podem ser úteis para a elucidação do status taxonômico de $R$. branneri e R. voulezi. Palavras-chave: endemismo, Heptapteridae, Rhamdia voulezi, Rhamdia branneri, Rhamdia quelen, ecomorfologia. 


\section{Introduction}

The Iguaçu River drainage is the largest basin among the rivers of Paraná State (Eletrosul 1978), and is known by its high endemism, estimated in $69.7 \%$ of the total of species (Baumgartner et al. 2012). This unique condition is probably caused by the basin isolation propitiated by the Iguaçu falls (Baumgartner et al. 2012) and a series of smaller falls on its main channel. Thus, the river has great hydroelectric potential, which has been explored for over thirty years, resulting in a large sequence of dams, whose reservoirs occupy at least $41 \%$ of its total extension (Júlio-Junior et al. 1997). Although its geomorphological and hydrographical features provide a high ecological importance for the basin, its fish fauna has been relatively poorly studied, since most studies are generally restricted to the lower Iguaçu River basin (Universidade... 2002, Baumgartner et al. 2012).

Rhamdia branneri (Haseman, 1911) and Rhamdia voulezi (Haseman, 1911) are two endemic catfish species of Iguaçu River, currently considered synonymous with Rhamdia quelen (see Silfvergrip 1996). Silfvergrip (1996) considered these two species synonymous with $R$. quelen, however, no exemplar from Iguaçu basin was examined by the author, as mentioned by Baumgartner et al. (2012). On the other hand, genetic studies conducted by Abucarma \& Martins-Santos (2001) demonstrated karyotypic differences between the species of Rhamdia of Iguaçu River basin.

Recently, Baumgartner et al. (2012) provided an identification manual of fishes from the lower Iguaçu River basin. The authors considered both species of Rhamdia valid based on the morphological divergences like length of the dorsal-fin rays, which is bigger in $R$. voulezi, touching the adipose-fin when adpressed, allied to the endemic condition of Iguaçu River and their genetic difference (Abucarma \& Martins-Santos 2001). Despite a minor superposition, the general body shape, mainly the relative body depth, can be also useful to identify the two species (Baumgartner et al. 2012). Additionally, differences in standard length (SL) at first maturation between $R$. branneri and $R$. voulezi are conspicuously different (Suzuki \& Agostinho 1997).

Based on these arguments, the present study sought to investigate ecomorphological differences between the two species of Rhamdia from the Iguaçu River basin. Trying to corroborate the previous studies that considered $R$. branneri and $R$. voulezi as distinct species, we expect that these fishes have some differences in their ecology since they coexist in the Iguaçu River basin. Despite their morphological similarities that resulted in taxonomical problems, ecomorphological studies can elucidate morphological aspects that might favor the coexistence of these fishes.

The principal idea in ecomorphology is that different morphologies can result in distinct ecological aspects, influencing the use of food resources, habitat occupation, and the species' fitness (Norton et al. 1995). Studies comparing congeneric and sympatric species may provide valuable evolutionary insights (Douglas \& Matthews 1999). Thus, the morphological aspects evidenced can be considered adaptive, showing divergences or convergences between the species.

In this way, we hypothesize that these closely related species show morphological differences that can be linked to differences in habitat use and feeding behavior, evidencing that $R$. branneri and $R$. voulezi, both from the Iguaçu River basin, are ecologically distinct and, therefore, are valid species. Furthermore, these aspects can provide useful information in explaining their coexistence in the Iguaçu River basin.

\section{Material and Methods}

1. Morphological measurements and ecomorphological indices. In order to characterize the ecomorphology of the specimens, linear measures and areas were obtained. Only aspects related to feeding behavior, habitat occupation and body hydrodynamics were analyzed (Gatz Jr. 1979, Winemiller 1991, Peres-Neto 1999). The morphological measurements adopted were: standard length, maximum body height, body midline height, maximum body width, caudal peduncle's length, height and width, head's length, height and width, mouth's width and height, eye's height, fins length and height and areas of the eyes and fins. Linear measures were obtained using a digital caliper to the nearest $0.01 \mathrm{~mm}$. The software AutoCad 2009 was used to compute areas of the fins and eyes from drawings of the structures that were previously digitalized. Ecomorphological indices were calculated using data obtained from linear measures and areas. The indices and their respective formulae were adopted according to previous studies (Gosline 1971, Gatz Jr. 1979, Watson \& Balon 1984, Wikramanayake 1990, Norton \& Brainerd 1993, Casatti \& Castro 1998, Pouilly et al. 2003, Breda et al. 2005, Hulsey \& García de León 2005, Kerfoot Jr. \& Schaefer 2006, Cochran-Biederman \& Winemiller 2010, Oliveira et al. 2010).

2. Biological material. Examined specimens are hosted in the Coleção Ictiológica do Núcleo de Pesquisas em Limnologia, Ictiologia e Aqüicultura (NUP) - Universidade Estadual de Maringá (Figure 1). All specimens were collected in reservoirs or next to their influence area. Numbers in parentheses indicate the number of specimens analyzed in their respective localities: Rhamdia branneri: NUP 3733 (9, Santa Clara Reservoir); 569 (3, Salto do Vau Reservoir); 10849 (12, Pinhãozinho River); 149 (3, Chopin Reservoir), Rhamdia voulezi : NUP 5271 (2, Salto Caxias Reservoir); 3721 (1, Capivara River, tributary of Jordão River); 5300 (6, Jordão Reservoir); 2426 (7, Jordão Reservoir); 1596 (7, Segredo Reservoir); 5289 (1, Caxias Reservoir); 2763 (1, Foz do Areia Reservoir); 568 (1, Salto do Vau Reservoir); 2905 (4, Iguaçu River).

3. Data analysis. From the ecomorphological indices, a principal component analysis (PCA) with a correlation matrix was performed in order to verify morphological patterns in the species. The criterion adopted for the axes' interpretation was the brokenstick (Jackson 1993). To test if there is a significant difference in morphology between the species, a multi response permutation procedure (MRPP - McCune \& Grace 2002) was conducted. This is a non-parametric analysis that uses groups determined a priori and a distance matrix. Thus, each Rhamdia species was assigned as a group, and the distance measure adopted was Euclidean distance.

In addition, a discriminant analysis (DA) was made using the forward-stepwise method with the aim to verify which morphological indices maximize the differences between the species. Similarly to

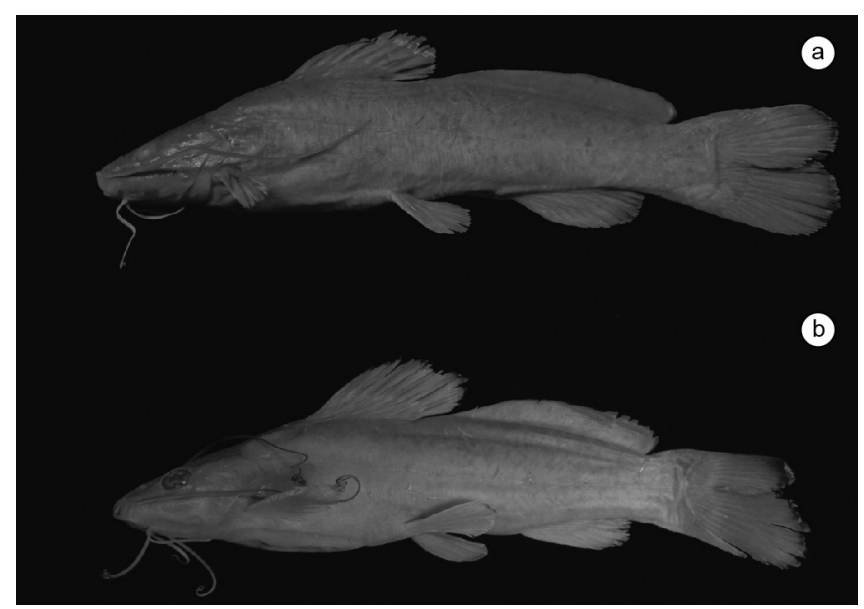

Figure 1. Specimens of Rhamdia branneri (a) and Rhamdia voulezi (b), NUP $10849(\mathrm{SL}=111.58 \mathrm{~mm})$ and NUP $2426(\mathrm{SL}=90.74 \mathrm{~mm})$, respectively. 
the MRPP, the DA has groups determined a priori, but differently, it provides a reclassification of the specimens according to morphology. The DA analysis can indicate if any individual show morphological features that can include it in another group.

All analyses were conducted using the software PcOrd (McCune \& Mefford 1999) except the DA that was performed in Statistica 7.0.

\section{Results}

The principal component analysis had two axes retained for interpretation, according to the broken-stick criterion. In general, there was a clear segregation between $R$. branneri and $R$. voulezi along the first axis (Figure 2). Some individuals of $R$. branneri had a separation in the second axis, and did not show evident segregation of $R$. voulezi in the first axis.

Most of the morphological characters that separated the Rhamdia species were related to body shape (Table 1). Therefore, the specimens of $R$. voulezi can be characterized by having more compressed and less depressed bodies (major values for this index indicates less depression of the trunk, according to Watson \& Balon 1984), longer caudal peduncle, wider mouth, and larger aspect ratio of the anal fin. The individuals of $R$. branneri can be characterized by having a higher mouth opening and anal fin. The MRPP showed significant differences $(\mathrm{A}=0.12 ; \mathrm{p}<0.001)$ in the ecomorphological indices between the groups (or species), validating the differences found in the ordination.

The DA revealed only one axis for interpretation with $R$. branneri showing negative scores and $R$. voulezi positive ones (Figure 3 ). The morphological attributes that separated the species were a higher anal fin for $R$. branneri, and a longer caudal peduncle, larger head width
Table 1. Eigenvalues and percentage of variation for each axis as well as the indices' loadings. The indices that were more important for interpretation are in bold.

\begin{tabular}{lrr}
\hline \multicolumn{1}{c}{ Indices } & PCA 1 & PCA 2 \\
\hline Compression index & $-\mathbf{0 . 8 7 4}$ & -0.211 \\
Depression index & $-\mathbf{0 . 7 6 6}$ & -0.289 \\
Relative length of the caudal peduncle & $-\mathbf{0 . 7 8 2}$ & -0.145 \\
Relative height of the caudal peduncle & 0.480 & -0.475 \\
Relative width if the caudal peduncle & -0.590 & $-\mathbf{0 . 5 6 8}$ \\
Relative length of the head & 0.231 & -0.184 \\
Relative height of the head & 0.295 & -0.402 \\
Relative width of the head & $-\mathbf{0 . 7 0 7}$ & -0.527 \\
Relative height of the mouth & $\mathbf{0 . 8 5 0}$ & -0.060 \\
Relative width of the mouth & -0.524 & -0.549 \\
Vertical eye position & 0.487 & 0.015 \\
Relative area of the eye & 0.230 & -0.113 \\
Relative height of the dorsal fin & 0.282 & $-\mathbf{0 . 6 0 1}$ \\
Relative area of the dorsal fin & 0.391 & -0.459 \\
Aspect ratio of the caudal fin & -0.530 & -0.200 \\
Relative height of the anal fin & $\mathbf{0 . 6 6 8}$ & -0.461 \\
Aspect ratio of the anal fin & $-\mathbf{0 . 6 3 4}$ & 0.152 \\
Aspect ratio of the pectoral fin & -0.278 & 0.596 \\
Aspect ratio of the pelvic fin & -0.531 & 0.456 \\
\hline Eigenvalue & 6.185 & 2.898 \\
Broken-stick Eigenvalue & 3.548 & 2.548 \\
Variability (\%) & 32.551 & 15.253 \\
Accumulated variability (\%) & 32.551 & 47.803 \\
\hline & &
\end{tabular}

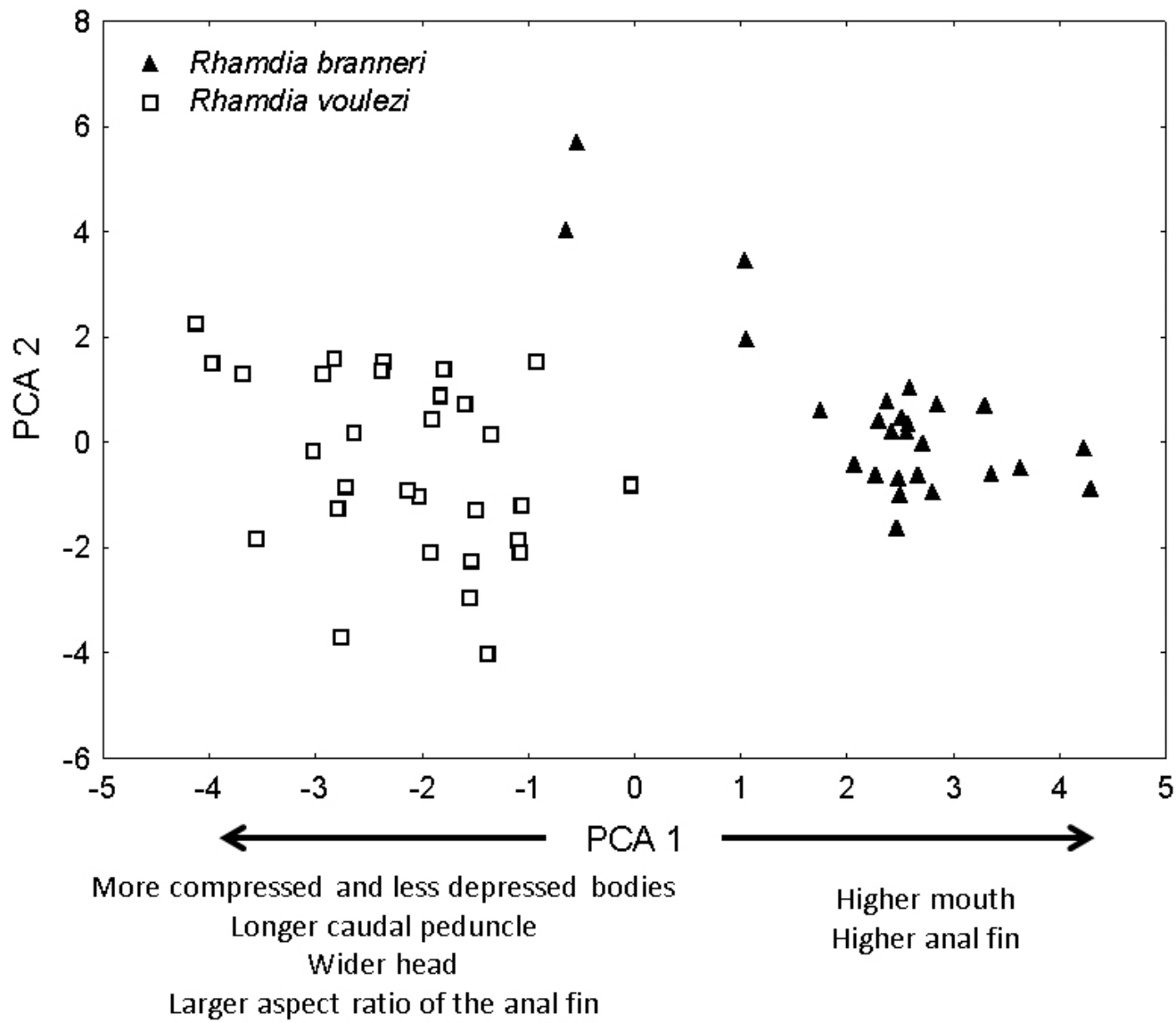

Figure 2. Principal component analysis scatterplot, showing the indices correlated with each axis. 

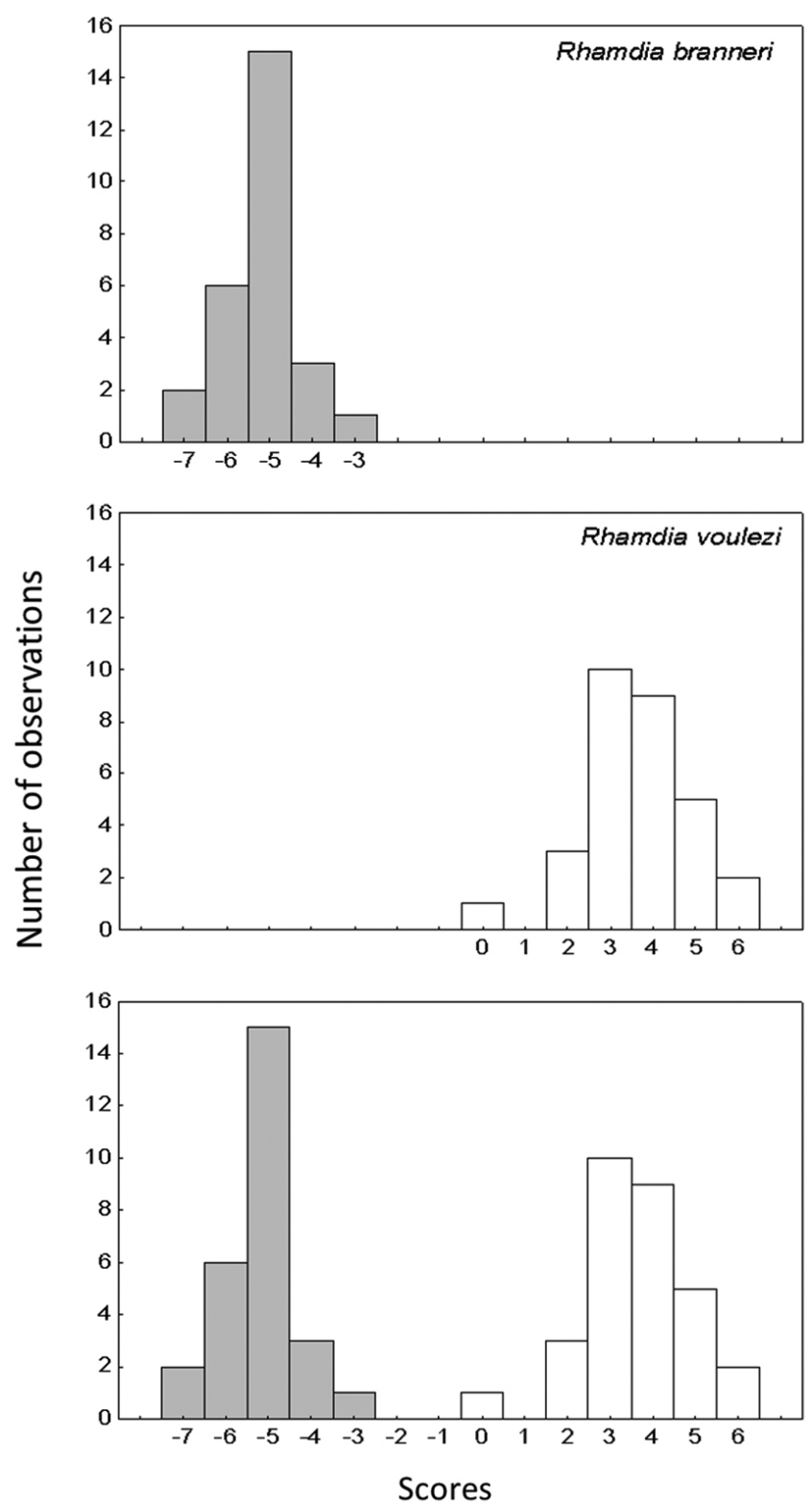

Figure 3. Histograms with the scores related to the first axis of the discriminant analysis.

Table 2. Eigenvalue and standardized function's coefficients. Indices that were more important for interpretation are in bold.

\begin{tabular}{ll}
\hline \multicolumn{1}{c}{ Indices } & Axis $\mathbf{1}$ \\
\hline Compression index & 0.032 \\
Relative length of the caudal peduncle & $\mathbf{0 . 8 5 0}$ \\
Relative head width & $\mathbf{0 . 6 7 6}$ \\
Depression index & $\mathbf{1 . 0 1 2}$ \\
Aspect ratio of the anal fin & 0.406 \\
Relative height of the anal fin & $-\mathbf{0 . 3 5 9}$ \\
Relative mouth width & 0.219 \\
Relative area of the eye & -0.175 \\
\hline Eigenvalue & 20.496 \\
Variability (\%) & 1.000 \\
\hline
\end{tabular}

and less depressed bodies for $R$. voulezi (Table 2). The reclassification of the individuals had an efficacy of $100 \%$, showing that the analyzed species are ecomorphologically distinct.

\section{Discussion}

The ecomorphological differences found in Rhamdia species are mostly related to swimming ability and habitat occupation. For example, $R$. voulezi had longer caudal peduncles and more compressed and less depressed bodies. The first characteristic indicates a better swimming performance mainly for short distance propulsion (Watson \& Balon 1984, Blake 2004). Compressed bodies indicate fishes that occupy habitats with slow water velocity and swimming capacity to explore many levels in the water column, performing vertical movements (Gatz Jr. 1979, Watson \& Balon 1984). On the other hand, $R$. branneri showed a higher anal fin, and more depressed bodies. The first is an ecomorphological characteristic related to stabilization in swimming, and the second indicates occupation of benthic habitats. Thus, based on the interpretation of ecomorphological indices, these results suggest a spatial segregation between the species, with $R$. branneri having morphological characteristics to occupy benthic habitats, and $R$. voulezi to occupy lentic and possibly pelagic habitats.

Studies concerning the feeding habits of these species are most focused on variations related to impoundments. Cassemiro et al. (2005) verified that, in Salto Caxias Reservoir, Rhamdia species fed exclusively on fishes after the impoundment, differently from the previous phases when invertebrates and crustaceans were also consumed. Other authors recorded significant differences in diet in the impoundment phases with $R$. voulezi consuming fishes, and $R$. branneri feeding on crustaceans and terrestrial insects (LoureiroCrippa \& Hahn 2006, Novakowski et al. 2007). The dietary changes can be certainly related to environmental changes caused by impoundments, since fishes and insects are abundant food resources in reservoirs (Hahn \& Fugi 2007).

Regarding the pre-impoundment phases, the diet of both Rhamdia species does not differ (Loureiro-Crippa \& Hahn 2006) with crustaceans and fish being consumed in similar proportions. On the other hand, other authors (Cassemiro et al. 2005, Novakowski et al. 2007 ) found dietary differences between $R$. branneri and $R$. voulezi. However, patterns in the diet of these fishes were not clearly defined, occurring local variations (Cassemiro et al. 2005).

Despite the discrepancy found in the studies, differences in the diet composition between the studied species indicate that, besides food abundance, other variables influence the use of food resources. The ecomorphological indices related to occupation of lentic habitats probably favored $R$. voulezi to feed on prey that explore the bottom, such as Cyphocharax modestus (Fernández-Yépez 1948), and fishes that can forage in shallow waters, such as some species of Astyanax (Hahn et al. 2004). These two prey types were the most consumed by piscivores in Salto Caxias Reservoir (Novakowski et al. 2007). The ecomorphological characteristics related to benthic fishes (depressed body) in $R$. branneri may have favored the ingestion of benthic crustaceans as Aegla sp. Additionally, a higher anal fin that provides stabilization in swimming can propitiate the consumption of allochthonous food, which drift in the water column, such as terrestrial insects (Gosline 1971, Gatz Jr. 1979).

Ecomorphological differences related to habitat occupation and use of food resources in congeneric species are well documented in the literature (e.g. Casatti et al. 2005, Balassa et al. 2004, Santos et al. 2011). Resource partitioning is considered the principal factor in structuring the aquatic communities (Ross 1986). Hence, the coexistence of the species can be favored by ecomorphological differences. The MRPP and the Discriminant Analysis resulted 
respectively in significant differences and total separation in ecomorphological aspects that can enable the characterization of the Rhamdia species as distinct ecological units.

Thus, the morphological segregation found in the present study and evidences in diet, reproduction, and genetic segregation coupled with the known endemism of Iguaçu river basin (Baumgartner et al. 2012) reinforce the arguments to refute the synonymy proposed by Silfvergrip (1996). However, the elucidation of the taxonomic status of $R$. branneri and $R$. voulezi can only be fulfilled with a complete taxonomic review, with morphological and molecular data, of populations attributed to $R$. quelen.

\section{Acknowledgements}

We express our appreciation to Nupélia (Núcleo de Pesquisas em Limnologia, Ictiologia e Aquicultura), to PEA (Programa de Pósgraduação em Ecologia de Ambientes Aquáticos Continentais), to PGB (Programa de Pós-graduação em Biologia Comparada) for their financial support and infrastructure, to Ichythyological Museum of Nupélia for the permission to carry out the research on their properties, Rosemara Fugi, Erivelto Goulart and Marlene Sofia Arcifa Froehlich for suggestions for the manuscript, and two anonymous referees for providing valuable suggestions. The authors also thank Coordenação de Aperfeiçoamento Pessoal de Nível Superior (CAPES/ Ministério da Educação) and CNPq (Conselho Nacional de Desenvolvimento Científico e Técnológico) for grants to FT Mise, LFC Tencatt, and F de Souza.

\section{References}

ABUCARMA, M. \& MARTINS-SANTOS, I.C. 2001. Karyotype and B chromosome of Rhamdia species (Pisces, Pimelodidae) endemic in the River Iguaçu basin. Cytologia 66:299-306. http://dx.doi.org/10.1508/ cytologia.66.299

BALASSA, G.C., FUGI, R., HAHN, N.S. \& GALINA, A.B. 2004. Dieta de espécies de Anostomidae (Teleostei, Characiformes) na área de influência do reservatório de Manso, Mato Grosso do Sul, Brasil. Iheringia, Ser. Zool. 94:77-82. http://dx.doi.org/10.1590/S0073-47212004000100014

BAUMGARTNER, G., PAVANELLI, C.S., BAUMGARTNER, D., BIFI, A.G., DEBONA, T. \& FRANA, V.A. 2012. Peixes do Baixo Rio Iguaçu. Eduem, Maringá, p.203.

BLAKE, R.W. 2004. Fish functional design and swimming performance. J. Fish Biol. 65:1193-1222. http://dx.doi.org/10.1111/j.0022-1112.2004.00568.x

BREDA, L., OLIVEIRA, E.F. \& GOULART, E. 2005. Ecomorfologia de locomoção de peixes com enfoque para espécies neotropicais. Acta Sci. Biol. Sci. 27:371-381. http://dx.doi.org/10.4025/actascibiolsci.v27i4.1271

CASATTI, L. \& CASTRO, R.M. 1998. A fish community of the São Francisco River headwater riffles, southeastern Brazil. Ichthyol. Explor. Freshw. 9:229-242.

CASATTI, L., ROCHA, F.C. \& PEREIRA, D.C. 2005. Habitat use by two species of Hypostomus (Pisces, Loricariidae) in southeastern brazilian streams. Biota Neotrop. 5(2): http://www.biotaneotropica.org.br/v5n2/ pt/abstract?article+bn02905022005 (último acesso em 15/01/2013).

CASSEMIRO, F.A.S., HAHN, N.S. \& DELARIVA, R.L. 2005. Estrutura trófica da ictiofauna, ao longo do gradiente longitudinal do reservatório de Salto Caxias (rio Iguaçu, Paraná, Brasil), no terceiro ano após o represamento. Acta Sci. Biol. Sci. 27:63-71. http://dx.doi.org/10.4025/ actascibiolsci.v27i1.1362

COCHRAN-BIEDERMAN, J.L. \& WINEMILLER, K.O. 2010. Relationships among habitat, ecomorphology and diets of cichlids in the Bladen River, Belize. Environ. Biol. Fish 88:143-152. http://dx.doi.org/10.1007/ s10641-010-9624-y

DOUGLAS, M.E. \& MATTHEWS, W.J. 1992. Does morphology predict ecology? Hypothesis testing within a freshwater stream fish assemblage. Oikos 65:213-224. http://dx.doi.org/10.2307/3545012
ELETROSUL. 1978. O impacto ambiental da ação do homem sobre a natureza - rio Iguaçu, Paraná, Brasil: reconhecimento da ictiofauna, modificações ambientais e usos múltiplos dos reservatórios. Florianópolis, p.33.

GATZ Jr, A.J. 1979. Ecological morphology of freshwater stream fishes. Tulane Stud. Zool. Bot. 21:91-124.

GOSLINE, W.A. 1971. Functional Morphology and Classification of Teleostean Fishes. University Press of Hawaii, Honolulu, p.208.

HAHN, N.S., FUGI, R. \& ANDRIAN, I.F. 2004. Trophic ecology of the fish assemblages. In The Upper Paraná River and its Floodplain: physical aspects, ecology and conservation (S.M. Thomaz, A.A. Agostinho \& N.S Hahn, eds.). Backhuys Publishers, Leiden, p.247-269.

HAHN, N.S. \& FUGI, R. 2007. Alimentação de peixes em reservatórios brasileiros: Alterações e conseqüências nos estágios iniciais de represamento. Oecol. Bras. 11:469-480. http://dx.doi.org/10.4257/ oeco.2007.1104.01

HULSEY, C.D. \& GARCÍA DE LEÓN, F.J. 2005. Cichlid jaw mechanics: linking morphology to feeding specialization. Funct. Ecol. 19:487-494. http://dx.doi.org/10.1111/j.1365-2435.2005.00987.x

JACKSON, D.A. 1993. Stopping rules in principal components analysis: a comparison of heuristical and statistical approaches. Ecology 74:22042214. http://dx.doi.org/10.2307/1939574

JÚLIO-JUNIOR, H.F., BONECKER, C. \& AGOSTINHO, A.A. 1997. Reservatório de Segredo e sua inserção na bacia do rio Iguaçu. In Reservatório de Segredo: bases ecológicas para o manejo (A.A. Agostinho \& L.C. Gomes, eds.). Eduem, Maringá, p.1-17.

KERFOOT Jr, J.R. \& SCHAEFER, J.F. 2006. Ecomorphology and habitat utilization of Cottus species. Environ. Biol. Fish 76:1-13. http://dx.doi. org/10.1007/s10641-006-9000-0

LOUREIRO-CRIPPA, V. E \& HAHN, N.S. 2006. Use of food resources by the fish fauna of a small reservoir (rio Jordão, Brazil) before and shortly after its filling. Neotrop. Ichthyol. 4:357-362. http://dx.doi.org/10.1590/ S1679-62252006000300007

McCUNE, B. \& GRACE, J.B. 2002. Analysis of ecological communities. MjM, Oregon, p.300.

McCUNE, B. \& MEFFORD, M.J. 1999. PC-ORD: multivariate analysis of ecological data. version 4.01. MjM Software Design, Oregon.

NORTON, S.F. \& BRAINERD, E.L. 1993. Convergence in the feeding mode of ecomorphologically similar species in the Centrarchidae and Cichlidae. J. Exp. Biol. 176:11-29.

NORTON, S.F., LUCZKOVICH, J.J. \& MOTTA, P.J. 1995. The role of ecomorphological studies in the comparative biology of fishes. Environ. Biol. Fish 44:287-304. http://dx.doi.org/10.1007/BF00005921

NOVAKOWSKI, G.C., HAHN, N.S. \& FUGI, R. 2007. Alimentação de peixes piscívoros antes e após a formação do reservatório de Salto Caxias, Paraná, Brasil. Biota Neotrop. 7:149-157. http://dx.doi.org/10.1590/ S1676-06032007000200017

OLIVEIRA, E.F., GOULART, E., BREDA, L., MINTE-VERA, C.V., PAIVA, L.R.S. \& VISMARA, M.R. 2010. Ecomorphological patterns of the fish assemblage in a tropical floodplain: effects of trophic, spatial and phylogenetic structures. Neotrop. Ichthyol. 8:569-586.

PERES-NETO, P.R. 1999. Alguns métodos e estudos em ecomorfologia de peixes de riacho. In Oecologia Brasiliensis Ecologia de peixes de riachos (E.P. Caramaschi, R. Mazzoni \& P.R. Peres-Neto, eds.). Universidade Federal do Rio de Janeiro, Rio de Janeiro, vol. 6, p.209-236.

POUILly, M., LiNO, F., BRETENOUX, J.G. \& ROSALES, C. 2003. Dietary-morphological relationship in a fish assemblage of the Bolivian Amazonian floodplain. J. Fish Biol. 62:1137-1158. http://dx.doi. org/10.1046/j.1095-8649.2003.00108.x

ROSS, S.T. 1986. Resource partitioning in fish assemblages: a review of field studies. Copeia 1986:352-388. http://dx.doi.org/10.2307/1444996 
SANTOS, F.L., CAMILO, F.L., ALBIERI, R.J. \& ARAÚJO, F.G. 2011. Morphological patterns of five fish species (four characiforms, one perciform) in relation to feeding habits in a tropical reservoir in South-eastern Brazil. J. Appl. Ichthyol. 27:1360-1364. http://dx.doi. org/10.1111/j.1439-0426.2011.01801.x

SILFVERGRIP, A.M.C. 1996. A systematic revision of the Neotropical catfish genus Rhamdia (Teleostei, Pimelodidae). Pp. 156. Stockholm: Department of Zoology, Stockholm University and Department of Vertebrate Zoology: Swedish Museum of Natural History.

SUZUKI, H.I. \& AGOSTINHO, A.A. 1997. Reprodução de peixes do reservatório de Segredo. In Reservatório de Segredo: bases ecológicas para o manejo (A.A. Agostinho \& L.C. Gomes, eds.). Eduem, Maringá, p.163-182.
UNIVERSIDADE ESTADUAL DE MARINGÁ. 2002. Reservatório de Salto Caxias: bases ecológicas para o manejo - Relatório final. Copel, Maringá, p.272. Elaborado por A.A. Agostinho, C.S. Pavanell, H.I. Suzuki, J.D. Latini, L.C. Gomes, N.S. Hahn, R. Fugi \& W.M. Domingues.

WATSON, D.J. \& BALON, E.K. 1984. Ecomorphological analysis of fish taxocenes in rainforest streams of northern Borneo. J. Fish Biol. 25:371384. http://dx.doi.org/10.1111/j.1095-8649.1984.tb04885.x

WIKRAMANAYAKE, E.D. 1990. Ecomorphology and biogeography of a tropical stream fish assemblage: evolution of assemblage structure. Ecology 71:1756-1764. http://dx.doi.org/10.2307/1937583

WINEMILLER, K.O. 1991. Ecomorphological diversification in lowland freshwater fish assemblages from five biotic regions. Ecol. Monogr. 61:343-365. http://dx.doi.org/10.2307/2937046 